\title{
Jejak Langkah Pengadilan Agama Purwakarta
}

\section{Sofia Gussevi, Melinda Maulani, Nur Aeni Muhfi}

Program Studi Ahwal Al-Syakhsiyyah

STAI DR. KH. EZ. Muttaqien Purwakarta

sofiagussevi@gmail.com,maulanimelinda@gmail.com,nuraeni.muhfi@gmail.com

\begin{tabular}{l}
\hline Informasi artikel \\
\hline Kata kunci: \\
Jejak Langkah \\
Pengadilan Agama \\
Purwakarta
\end{tabular}

Keywords:

Footsteps

Purwakarta Religious

Court

\begin{abstract}
ABSTRAK
Penelitian ini dilatarbelakangi dari keprihatinan penulis terhadap minimnya referensi yang digunakan dalam mengampu mata kuliah Peradilan Agama di Indonesia. Penelitian ini merupakan pengimplementasian salah satu model yang digun akan dalam pengkajian Peradilan Agama di Indonesia. Model pengkajian Peradilan Agama di Indonesia yang dimaksud adalah Model Pengkajian Sosio Historis. Pengkajian ini dititikberatkan pada kronologi pertumbuhan dan perkembangan peradilan termasuk badan peradilan dalam suatu rentang waktu tertentu atau dalam suatu kawasan kebudayaan (lokal) tertentu. Dalam hal ini peneliti mengambil objek penelitiannya Pengadilan Agama Purwakarta. Penelitian ini bertujuan untuk mengetabui unsur-unsur perubahan yang terjadi dalam perkembangan Pengadilan Agama Purwakarta dan dasar pertimbangan perubahan Pengadilan Agama Purwakarta dilakukan. Metode yang digunakan adalah metode kualitatif deskriptif. Berdasarkan hasil penelitian menunjukkan bahwa unsur-unsur perubahan yang terjadi dalam perkembangan Pengadilan Agama Purwakarta adalah sarana prasarana, reformasi birokrasi dan jumlah perkara yang diselesaikan. Dasarpertimbangan perubahan Pengadilan Agama Purwakarta dilakukan adalah kondisi sosial budaya masyarakat dan optimalisasi pelayanan kepada masyarakat.
\end{abstract}

\section{ABSTRACT}

The Footsteps of the Purwakarta Religious Court, This research is motivated by the author's concern about the lack of references used in teaching the Religious Courts course in Indonesia. This research is an implementation of one of the models used in the study of the Religions Courts in Indonesia. The model for the study of the Religious Courts in Indonesia is the Socio-Historical Assessment Model. This study focuses on the chronology of the growth and development of the judiciary including the judiciary within a certain period of time or in a certain (local) cultural area. In this case the researcher took the object of his research at the Purwakarta Religious Court. This study aims to determine the elements of changes that occur in the development of the Purwakarta Religious Court and the basis for consideration of changes in the Purwakarta Religious Court. The method used is descriptive qualitative method. Based on the results of the research, it shows that the elements of changes that have occurred in the development of the Purwakarta Religious Court are the facilities for the reform of the birography and the number of cases resolved. The basis for considering the changes in the Purwakarta Religious Court is the socio-cultural conditions of the community and the optimization of services to the community. 


\section{A. Pendahuluan}

Peradilan Agama merupakan kekuasaan negara dalam menerima, memeriksa, mengadili, memutus dan menyelesaikan perkara-perkara tertentu antara orang-orang yang beragama Islam untuk menegakkan hukum dan keadilan. Adapun Pengadilan Agama adalah pengadilan tingkat pertama dalam lingkungan Peradilan Agama. Hal itu menunjukkan bahwa Pengadilan Agama adalah satuan (unit) penyelenggara Peradilan Agama. Adapun satuan penyelenggara peradilan pada tingkat kedua (banding) adalah Pengadilan Tinggi Agama (PTA), sedangkan pengadilan pada tingkat kasasi adalah Mahkamah Agung (MA) ${ }^{1}$. Dengan demikian, pengadilan adalah badan peradilan yang melaksanakan kekuasaan kehakiman untuk menegakkan hukum dan keadilan.

Pengadilan Agama di Indonesia merupakan salah satu lembaga yang sangat tua, sehingga dalam sejarahnya yang panjang, Pengadilan Agama mengalami berbagai pasang surut. Pada mulanya ia diorganisasikan secara sederhana, kemudian menjadi salah satu pelaksana kekuasaan pemerintah dalam bentuk dan wewenang yang beraneka ragam. Ia mengalami perkembangan yang pesat dalam struktur, kekuasaan dan prosedurnya. Posisinya pun semakin penting, terutama dalam menjalankan fungsinya untuk menegakkan hukum dan keadilan.

Ke depannya, Peradilan Agama akan dihadapkan dengan berbagai peluang dan tantangan yang akan menentukan sejauh mana eksistensinya dalam kehidupan masyarakat. Taufiq melakukan analisis SWOT (Strength, Weakness, Opportunity, Threat) ${ }^{2}$ untuk mengidentifikasi sejauh mana prospek Peradilan Agama ke depan. Berkaitan dengan analisis SWOT yang dilaksanakan oleh Taufiq tersebut, hal ini juga yang menarik menurut peneliti untuk dikaji mengenai eksistensi Pengadilan Agama Purwakarta, walaupun ada kelemahan (Weakness) Pengadilan Agama Purwakarta dan ancaman (Threat) terhadap Pengadilan Agama Purwakarta untuk menjadi semakin lebih maju, di samping itu ada kekuatan (Strength) dan kesempatan (Opportunity) yang dimiliki

\footnotetext{
${ }^{1}$ Cik Hasan Bisri, Peradilan Agama di Indonesia,(PT RajaGrafindo Persada, 2000), 7. Penjela san ini juga terdapat dalam Cik Hasan Bisri, Peradilan Islam dalam Tatanan Masyarakat Indonesia, (Bandung: Rosdakarya, 1997), 36. Hal yang sama juga terdapat dalam Cik Hasan Bisri, Bunga Rampai Peradilan Islam di Indonesia, (Bandung: Ulul Albab Press, 1997), 108-109
}

${ }^{2}$ Bisri, Peradilan Agama ..., 262-263 
oleh Pengadilan Agama Purwakarta dalam menunjukkan eksistensinya khususnya di Kabupaten Purwakarta, Propinsi Jawa Barat umumnya dan lebih luas lagi di negara Indonesia.

Berkenaan dengan Pengadilan Agama Purwakarta dalam menunjukkan eksistensinya, tidak hanya di wilayah Kabupaten Purwakarta ataupun Propinsi Jawa Barat umumnya tetapi juga sudah menunjukkan eksistensinya yang lebih luas lagi yaitu wilayah negara Republik Indonesia. Hal ini terlihat dari Piagam Penghargaan Direktorat Jenderal Badan Peradilan Agama Mahkamah Agung Republik Indonesia Nomor : 006/DjA/PTSP/IX/2018 yang diberikan kepada Pengadilan Agama Purwakarta Kelas IB sebagai JUARA I dalam Implementasi Pelayanan Terpadu Satu Pintu (PTSP) di Lingkungan Direktorat Jenderal Badan Peradilan Agama Mahkamah Agung Republik Indonesia.

Sebenarnya fakta mengenai Pengadilan Agama Purwakarta tersebut sudah peneliti temui ketika menjadi pembimbing Praktek Profesi Lapangan (PPL) dari tahun 2014 di Pengadilan Agama Purwakarta. Hal ini terungkap berdasarkan data yang ada di Kantor Pengadilan Agama Purwakarta dan fakta yang terjadi selama peneliti menjadi pembimbing Praktek Profesi Lapangan (PPL) mahasiswa STAI DR. KHEZ. Muttaqien Purwakarta sampai tahun 2019 .

Berkaitan dengan itu, dalam penelitian "Jejak Langkah Pengadilan Agama Purwakarta" ini, peneliti menggunakan model pengkajian Sosio Historis. Pengkajian yang dititikberatkan pada kronologi pertumbuhan dan perkembangan Peradilan Islam dalam suatu rentangan waktu tertentu, atau dalam suatu kawasan kebudayaan (lokal) tertentu. Mengenai rentang waktu di sini, peneliti lebih fokus kepada 5 tahun terakhir yaitu tahun 2016-2020. 


\section{B. Pembahasan}

1. Unsur-unsur perubahan yang terjadi dalam perkembangan Pengadilan Agama Purwakarta

Unsur-unsur perubahan yang terjadi dalam perkembangan Pengadilan Agama Purwakarta ini antara lain :

\section{a. Sarana prasarana}

Sebenarnya sejak zaman penjajahan pemerintah Hindia Belanda, di Purwakarta telah berdiri Pengadilan Agama yang pada waktu itu disebut Raad Agama atau "Priester Raad" Regentschap Karawang berkedudukan di Purwakarta. Untuk menertibkan Peradilan Agama, pemerintah Belanda mengeluarkan Keputusan Nomor 24 tanggal 19 Januari 1882 yang dimuat dalam Stbl. 1882 No. 152 tentang Pembentukan Peradilan Agama di Jawa dan Madura, dan berlaku mulai tanggal 01 Agustus 1882 dan termuat dalam Stbl. 1882 No. 153³.

Pada awalnya luas tanah Pengadilan Agama Purwakarta seluas 500 $\mathrm{m}^{2}$ dengan hak guna bangunan tanah milik Pemerintah Kabupaten Purwakarta Nomor 29/HK.021.1/V/SK/1977. ditambah dengan tanah persil yang dimiliki secara Hak Milik seluas $250 \mathrm{~m}^{2}$ untuk rumah dinas. Gedung Pengadilan Agama Purwakarta dibangun pada tahun 1979 dengan luas bangunan $150 \mathrm{~m}^{2}$. Kemudian tahun 1982 dilaksanakan rehabilitasi/perluasan gedung balai sidang sehingga luas bangunan seluruhnya $383,4 \mathrm{~m}^{2}$, sedangkan bangunan untuk rumah dinas $69 \mathrm{~m}^{24}$.

Sejak awal berdirinya gedung kantor Pengadilan Agama Purwakarta beralamat di Jalan Gandanegara No. 25 Purwakarta berdampingan dengan Setda Purwakarta serta Rumah Dinas Bupati Purwakarta, dengan kondisi gedung yang sederhana. Mengingat gedung yang lama sudah tidak representatif, barulah pada tahun 2016 Pengadilan Agama Purwakarta menempati gedung baru setelah selesai

\footnotetext{
${ }^{3}$ Ridwan Anwar, Syukuran Menempati Gedung Baru PA Purwakarta Berlangsung Istimewa, https://badilag.mahkamahagung.go.id/seputar-peradilan-agama/berita-daerah/syukuran-menempa tigedung-baru-pa-purwakarta-berla ngsung-istimewa-23-3. Diakses pada 12 September 2020

${ }^{4}$ Jonni Hida yatullah, Sejarah Pengadilan, https://www.pa-purwakarta.go.id/tentang-pengadian/pro filepenga dilan/sejarah-pengadilan. Diakses pada 10 September 2020
} 
dibangun dengan anggaran dari Mahkamah Agung RI. Gedung baru Pengadilan Agama Purwakarta itu berada di Jalan Ir. H. Djuanda Nomor 03 Purwakarta.

Dengan demikian tergambar bahwa sarana prasarana khususnya tanah dan gedung yang dimiliki oleh Pengadilan Agama Purwakarta terus terjadi peningkatan. Sebelumnya Pengadilan Agama Purwakarta menempati gedung yang sederhana di Jalan Gandanegara No. 25 Purwakarta. Hal ini peneliti lihat sendiri dan merasakan sendiri pada waktu peneliti menjadi Dosen Pembimbing dalam kegiatan Praktek Profesi Lapangan (PPL) Program Studi Ahwal Al-Syakhshiyyah STAI DR. KH. EZ. Muttaqien Purwakarta tahun Akademik 2014/2015, fasilitas yang dimiliki oleh Pengadilan Agama Purwakarta sangat terbatas dan belum memadai. Barulah pada tahun 2016 Pengadilan Agama Purwakarta menempati gedung baru setelah selesai dibangun dengan anggaran dari Mahkamah Agung RI. Gedung yang megah dan luas, menurut peneliti sangat menunjang Pengadilan Agama Purwakarta dalam memberikan pelayanan maksimal kepada masyarakat pencari keadilan.

\section{b. Reformasi birokrasi}

Pelaksanaan Reformasi Birokrasi dan Pembangunan Zona Integritas ${ }^{5}$ menuju Wilayah Bebas Korupsi (WBK)/Wilayah Birokrasi Bersih dan Melayani (WBBM) yang telah dilaksanakan Mahkamah Agung dan badan peradilan yang ada di bawahnya bertujuan untuk meningkatkan kualitas kinerja organisasi dan membentuk SDM (Sumber Daya Masyarakat) aparatur peradilan yang profesional. Salah satu area perubahan yang bertujuan pada Reformasi Birokrasi adalah terwujudnya Pola Pikir (Mind Set) dan Budaya Kerja (Culture Set) dimana kedua hal tersebut selaras dengan tata nilai Mahkamah Agung. Implementasi dari hal tersebut akan terlaksana jika mucul dari dalam internal individu-individu bukan karena faktor eksternal. Untuk membentuk Birokrat dan Birokrasi yang efektif, efisien dan produktif serta profesional maka penerapan nilai-nilai organisasi yang diyakini kebenarannya harus menjadi dasar pelaksanaan institusi sehari-hari di lingkungan Mahkamah Agung dan badan peradilan yang ada di bawahnya. Oleh karena itu 8

\footnotetext{
${ }^{5}$ Zona Integritas (ZI) merupakan suatu program Mahkamah Agung dalam upaya menuju Wila yah Be bas Korupsi(WBK) dan Wila yah Birokrasi Bersih dan Melayani. Pengadilan Aga ma Purwakarta dalam mela ksanakanZona Integritas dengan menuangkannya dalam bentuk banner dan spanduk.
} 
nilai utama Mahkamah Agung harus tertancap kuat dan diimplementasikan dalam pikiran, ucapan serta tindakan setiap individu dalam kehidupan berorganisasi dengan pola pikir yang melayani masyarakat, profesionalitas kinerja yang tinggi dan berorientasi pada hasil .

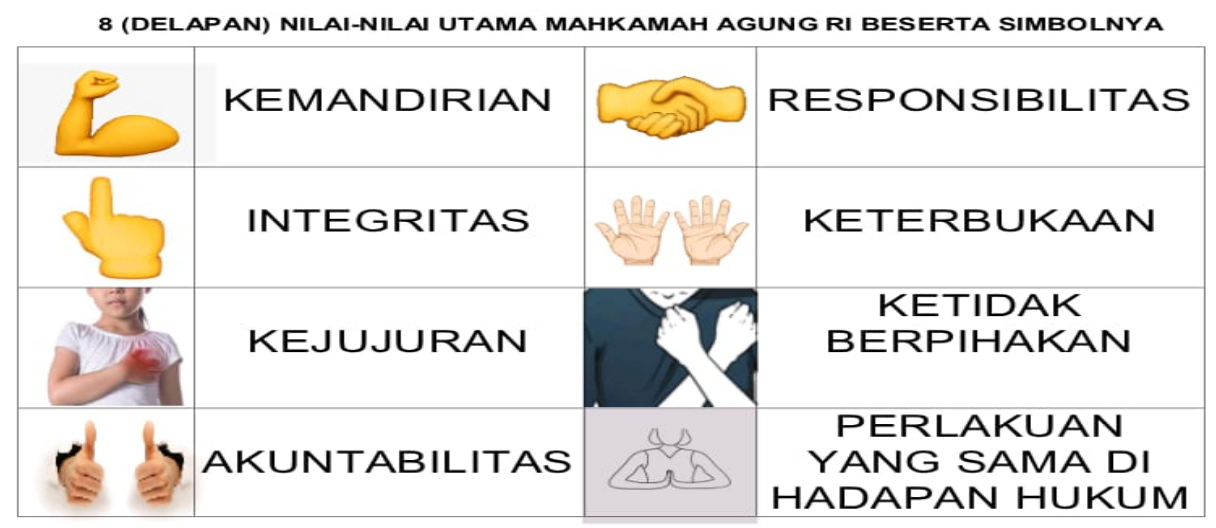

Berkaitan dengan reformasi birokrasi, perkembangan Pengadilan Agama Purwakarta terlihat dari pencanangan Pembangunan Zona Integritas (ZI) Menuju Wilayah Bebas Korupsi (WBK), Wilayah Birokrasi Bersih dan Melayani (WBBM) pada Pengadilan Agama Purwakarta yang sudah dimulai dari tahun 2018. Zona Integritas dimaksudkan bahwa Pengadilan Agama Purwakarta berkonsisten dan bertekad dengan teguh untuk bekerja dan memberikan pelayanan dengan baik kepada masyarakat. Pengadilan Agama Purwakarta sudah mempunyai aplikasi dalam menunjang kinerja dan pelayanan yang cepat kepada masyarakat, para pihak yang berperkara sudah bisa mengambil antrian di rumah masing-masing dengan menggunakan HP Android melalui aplikasi Siansidi Mobile.

Sehubungan dengan Zona Integritas yang dilaksanakan oleh Pengadilan Agama Purwakarta, Pengadilan Agama Purwakarta menunjukkan eksistensinya tidak hanya di wilayah Kabupaten Purwakarta ataupun Propinsi Jawa Barat umumnya tetapi juga sudah menunjukkan eksistensinya yang lebih luas lagi yaitu wilayah negara Republik Indonesia. Hal ini terlihat dari Piagam Penghargaan Direktorat Jenderal Badan Peradilan Agama Mahkamah Agung Republik Indonesia Nomor : 006/DjA/PTSP/IX/2018 yang diberikan kepada Pengadilan Agama

${ }^{6} 8$ Nilai Utama Mahkamah Agung, https://pa-purwodadi.go.id/index.php/25-halaman-depan/beritakegiatan/428-8-nilai-utama-mahkamah-agung. Dia kses pada 7 November 2020 
Purwakarta Kelas IB sebagai JUARA I dalam Implementasi Pelayanan Terpadu Satu Pintu (PTSP) di Lingkungan Direktorat Jenderal Badan Peradilan Agama Mahkamah Agung Republik Indonesia. Peneliti sebagai dosen pembimbing dan mahasiswa Praktek Profesi Lapangan Program Studi Ahwal Al-Syakhshiyyah STAI. DR. KH. EZ. Muttaqien Purwakarta tahun 2018 ikut andil dan ikut bangga atas prestasi yang diraih oleh Pengadilan Agama Purwakarta.

\section{c. Jumlah perkara yang diputus}

Penelitian ini lebih fokus pada 5 tahun terakhir yaitu tahun 2016-2020, karena pada rentang waktu inilah banyak terjadi perkembangan di Pengadilan Agama Purwakarta. Salah satunya mengenai jumlah perkara yang diterima dan diselesaikan oleh Pengadilan Agama Purwakarta dari tahun ke tahun terlihat ada peningkatan. Hal itu dapat terlihat dari tabel dan grafik berikut ini :

\section{TABEL REKAPITULASI KEADAAN PERKARA \\ PENGADILAN AGAMA PURWAKARTA}

TAHUN 2016-2020

\begin{tabular}{|l|c|c|c|c|c|}
\hline & 2016 & 2017 & 2018 & 2019 & 2020 \\
\hline Perkara yang Diterima & 1876 & 1806 & 2163 & 2537 & 2911 \\
\hline Sisa Perkara Tahun Sebelumnya & 225 & 278 & 268 & 308 & 252 \\
\hline Perkara yang Diputus & 1823 & 1816 & 2123 & 2593 & 2959 \\
\hline
\end{tabular}

Sumber : Pengadilan Agama Purwakarta 


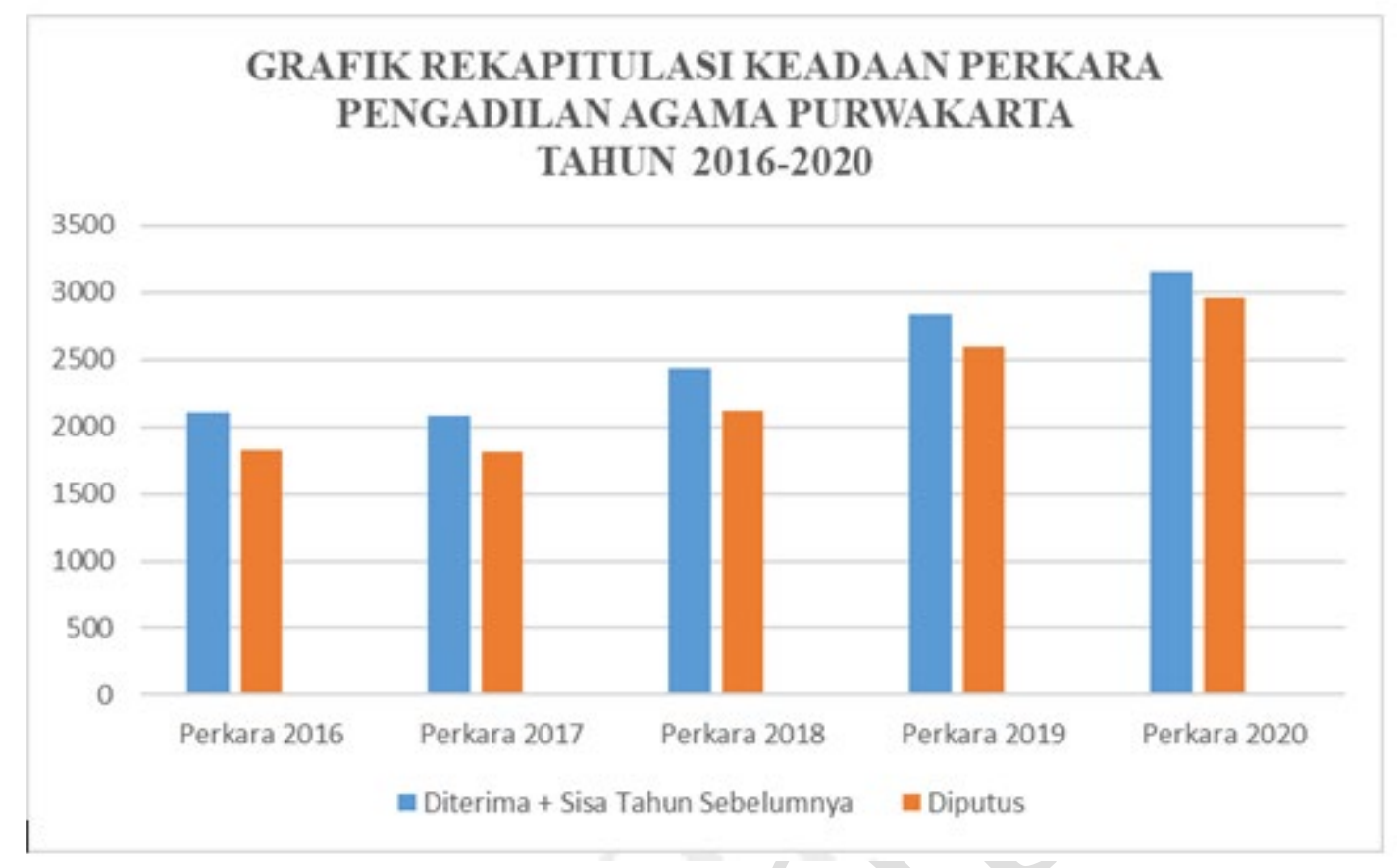

Dari tabel dan grafik di atas terlihat perkara yang diterima dan diputus oleh Pengadilan Agama Purwakarta ada peningkatan dari segi jumlahnya dari tahun ke tahun. Peningkatan jumlah perkara ini juga merupakan pengaruh dari penerapan Zona Integritas oleh Pengadilan Agama Purwakarta sehingga kesadaran hukum masyarakat semakin meningkat. Kemudian mengenai peningkatan jumlah perkara khususnya angka perceraian dan apabila dihubungkan juga dengan kondisi sosial budaya masyarakat, terlihat perkara perceraian yang diselesaikan oleh Pengadilan Agama Purwakarta sangat signifikan peningkatannya pada kondisi pandemi Covid19 sekarang ini.

Dengan adanya Pembangunan Zona Integritas menuju Wilayah Bebas Korupsi (WBK)/Wilayah Birokrasi Bersih dan Melayani (WBBM), termasuk Pengadilan Agama Purwakarta juga melaksanakan Zona Integritas ini ${ }^{7}$. Jumlah perkara yang diterima dan diputus oleh Pengadilan Agama Purwakarta menjadi lebih meningkat. Dalam hal positifnya, ini membuktikan bahwa masyarakat semakin sadar hukum. Bagi masyarakat yang belum memiliki Buku Nikah, maka banyak

\footnotetext{
${ }^{7}$ Jonni Hida yatulloh, Administrator dan Petugas Pendaftaran/Ecourt di Pengadilan Aga ma Pu rwakarta, Wawancara Mendalam, 4 November 2020
} 
masyarakat yang mau mengisbatkan pernikahannya. Masyarakat yang sebelumnya banyak melakukan cerai di luar sidang Pengadilan Agama, menjadi lebih sadar hukum dan memilih mengajukan perceraiannya ke Pengadilan Agama Purwakarta.

Mengenai peningkatan angka perceraian ini, Direktur Jenderal Badan Peradilan Agama Mahkamah Agung (Dirjen Badilag MA), Aco Nur, menjelaskan, selama pandemi Covid-19, total perceraian di seluruh wilayah Indonesia mengalami peningkatan. Hal itu disebabkan adanya Pembatasan Sosial Berskala Besar (PSBB) yang diterapkan hampir di seluruh wilayah di Indonesia. Kondisi itu memaksa aktivitas ekonomi berkurang, hingga memicu pemutusan hubungan kerja (PHK) karyawan. Pada periode April dan Mei 2020, terlihat pendaftaran cerai masih di bawah angka 20 ribu yang tercatat di PA seluruh Indonesia. Jumlah itu meningkat pada masa adaptasi kebiasaan baru yang melonjak menjadi 57 ribu perceraian pada bulan Juni sampai Juli 2020. Di antara jumlah propinsi terbanyak penyumbang angka perceraian adalah wilayah Jawa Barat berada di urutan teratas. Kemudian Kota Semarang dan Surabaya menjadi lokasi yang paling banyak mengajukan cerai ${ }^{8}$.

Kalau dilihat secara skala Indonesia, propinsi terbanyak penyumbang angka perceraian adalah wilayah Jawa Barat berada di urutan teratas. Kemudian Kota Semarang dan Surabaya menjadi lokasi yang paling banyak mengajukan cerai ${ }^{9}$. Termasuk di Pengadilan Agama Purwakarta, pada masa pandemi Covid-19 ini terjadi peningkatan angka perceraian ${ }^{10}$. Perkara perceraian yang dominan diterima dan diselesaikan adalah cerai gugat yaitu perceraian yang diajukan oleh pihak istri. Menurut penulis, hal ini disebabkan adanya Pembatasan Sosial Berskala Besar (PSBB) yang diterapkan hampir di seluruh wilayah di Indonesia termasuk di wilayah Purwakarta. Kondisi itu memaksa aktivitas ekonomi berkurang, hingga memicu pemutusan hubungan kerja (PHK) karyawan. Purwakarta merupakan daerah industri. Hal ini juga berimbas kepada ekonomi rumah tangga. Masalah ekonomi ini salah satu faktor penyumbang konflik dalam rumah tangga. Rumah tangga yang

8 Erik Purnama Putra, PSBB Picu Kenaikan Perceraian, Ini Analisis Dirjen Badilag, https://republika.co.id/berita/qfrjas484/psbb-picu-kenaikan-perceraian-ini-analisis-dirjen-badila g. Diakses pada 4 Desember 2020

${ }^{9}$ Ibid.

${ }^{10}$ Abdul Ghaffar Mubtadi, Sekretaris Pengadilan Agama Purwakarta, Wawancara Mendalam, 7 September 2020 
tidak maksimal melakukan manajemen konflik dalam rumah tangga mereka terutama mengenai masalah ekonomi yang dihadapi, maka mereka memutuskan untuk mengajukan perceraian ke Pengadilan Agama Purwakarta.

\section{Dasar pertimbangan perubahan Pengadilan Agama Purwakarta dilakukan}

Dasar pertimbangan perubahan Pengadilan Agama Purwakarta dilakukan, antara lain :

a. Kondisi sosial budaya masyarakat.

Pengadilan Agama Purwakarta sebagai lembaga peradilan yang melaksanakan fungsi kekuasaan kehakiman (yudikatif) dalam wilayah hukum Propinsi Jawa Barat, mempunyai tugas pokok menerima, memeriksa, mengadili dan menyelesaikan perkara yang diajukan sebagaimana diatur dalam Undang-Undang Nomor 7 tahun 1989 tentang Peradilan Agama yang telah diubah dengan Undangundang Nomor 3 tahun 2006.

Penyelenggaraan tugas pokok tersebut berkaitan erat dengan tuntutan masyarakat akan kemandirian hukum dan keadilan, penegakan supremasi hukum, proses peradilan yang cepat, sederhana dan biaya ringan, terhadap lembaga peradilan termasuk Pengadilan Tinggi Agama Bandung dan Pengadilan Agama dalam wilayah hukumnya menandakan signifikannya penyusunan suatu rencana stratejik, sebagai kerangka acuan untuk mewujudkan cita-cita hukum.

Rencana stratejik Pengadilan Agama Purwakarta ini merupakan rumusan stratejik dalam penyelenggaraan tugas pokok dan fungsi (tupoksi) lembaga peradilan dalam wilayah hukumnya, peningkatan pelayanan hukum kepada masyarakat. Penyusunan rencana strategis Pengadilan Agama Purwakarta tersebut disusun dengan memperhatikan perkembangan hukum dan masyarakat di Kabupaten Purwakarta ${ }^{11}$, kondisi internal Pengadilan Agama Purwakarta serta dengan memperhatikan kondisi perkembangan hukum dan masyarakat secara nasional.

Pengadilan Agama Purwakarta terus berusaha melakukan perubahan. Perkembangan dunia digital tidak lagi sekedar mempengaruhi, bahkan mengubah perilaku dan kebiasaan masyarakat. Digitalisasi kehidupan yang semakin

\footnotetext{
${ }^{11}$ Jonni Hidayatulla h, Sejarah Pengadilan, https://www.pa-purwakarta.go.id/tentang-pengadian/pro filepenga dilan/sejarah-pengadilan. Dia kses pada 10 September 2020
} 
berkembang pesat ke depan ini juga dimanfaatkan oleh Pengadilan Agama Purwakarta.

\section{b. Optimalisasi pelayanan di Pengadilan Agama Purwakarta}

Mahkamah Agung dan jajaran Pengadilan di bawahnya senantiasa berupaya menata, meningkatkan, dan menyederhanakan pelayanan publik dengan cara menera pkan sistem Pelayanan Terpadu Satu Pintu ${ }^{12}$ (PTSP). Melalui PTSP ini Mahkamah Agung ingin memberikan pelayanan prima dalam hal pelayanan publik yang proses pengelolaannya dimulai dari tahap awal sampai akhir/terbitnya sebuah dokumen dilakukan di dalam satu tempat. Wujud keseriusan Mahkamah Agung dan jajaran Pengadilan di bawahnya terhadap penerapan PTSP tersebut dilakukan dengan dikeluarkannya Keputusan Direktur J enderal Badan Peradilan Umum Nomor 77/DJU/SK/HM02.3/2/2018 tentang Pedoman Stand ar Pelayanan Terpadu Satu Pintu (PTSP) Pada Pengadilan Agama.

Pengadilan Agama Purwakarta sebagai lembaga Peradilan di bawah Mahkamah Agung, bahwa sejak tahun 2018 Pengadilan Agama Purwakarta sudah mulai menerapk an standar PTSP sesuai Keputusan Direktur Jenderal Badan Peradilan Umum Nomor 77/DJU/SK/HM02.3/2/2018 tentang Pedoman Standar Pelayanan Terpadu Satu Pintu (PTSP) Pada Pengadilan Agama. Ruang lingkup PTSP di Pengadilan Agama Purwakarta ini meliputi seluruh pelayanan administrasi yang menjadi lingkup kompetensi/kewenangannya sebagaimana diatur dalam Keputusan Ketua Mahkamah Agung tentang Standar Pelaya nan Peradilan dan peraturan perundangan lainnya yang berlaku ${ }^{13}$.

Melihat perkembangan sosial budaya masyarakat dan dalam upaya mengoptimalkan pelayanan kepada masyarakat, sosialisasi pembangunan Zona Integritas (ZI) terus dilakukan oleh Pengadilan Agama Purwakarta. Hal ini terlihat pada tanggal 28 Juli 2020 yang bertempat di Aula Sidang Utama, Pengadilan Agama Purwakarta mengadakan Sosialisasi Pembangunan Zona Integritas Menuju Wilayah Bebas Korupsi (WBK), Wilayah Birokrasi Bersih dan Melayani (WBBM) pada Pengadilan Agama Purwakarta, dengan mengundang sejumah advokat, LBH, KUA, Kantor Pos dan BPS yang berada di wilayah Kabupaten Purwakarta ${ }^{14}$.

\footnotetext{
${ }^{12}$ Jonni Hidayatullah, Penerapan Pelayanan Terpadu Satu Pintu (PTSP Online), https://www.pa${ }^{13}$ Ibid. purwakarta.go.id/perubahan/pela yanan-terpadu-satu-pintu. Diakses pada 2 November 2020

${ }^{14}$ Jonni Hidayatullah, Sosialisasi Pembangunan Zona Integritas (ZI), http://www.papurwakarta.go.id/seputar-peradila n/397-sosialisa si-pembangunan-zona-integritas-zi. Diakses pa da 7 November 2020
} 
Muttaqien, Vol. 2. No. 2 Juli 2021, 125 - 141

Selain itu, peran dan pelayanan Posbakum yang ada di lingkungan Pengadilan Agama Purwakarta dan implementasi E-Court dan Pelayanan Terpadu Satu Pintu (PTSP) dapat meningkatkan kwalitas pelayanan kepada masyarakat pencari keadilan.

Pengadilan Agama Purwakarta juga melakukan terobosan baru berkaitan dengan pengiriman produk layanan berupa salinan putusan dan akta cerai melalui kerja sama pengiriman melalui kantor Pos di wilayah Purwakarta. Hal tersebut bertujuan memberikan kemudahan masyarakat terutama mereka yang domisilinya relatif jauh dari Pengadilan Agama Purwakarta, terlebih lagi dalam waktu dekat Dirjen Badilag akan mengeluarkan blanko akta cerai yang dapat dengan mudah dicek keasliannya melalui salah satu aplikasi yang telah tesedia di google play store ${ }^{15}$. Denga adanya penandatanganan MOU (Memorandum Of Understanding) antara Pengadilan Agama Purwakarta dengan PT. Pos Kabupaten Purwakarta, diharapkan semakin meningkatkan kualitas pelayanan Pengadilan Agama Purwakarta terhadap para pencari keadilan.

Kemudian mengenai sarana prasarana juga terus dibangun oleh Pengadilan Agama Purwakarta sebagai wujud pelayanan prima kepada masyarakat, yaitu dibangun mushalla "Al-Mahkamah" yang sudah mulai digunakan pada bulan Agustus 2020 yang dibangun dari sumber swadaya ${ }^{16}$. Sebelumnya yang digunakan tempat shalat dengan memanfaat salah satu ruangan yang menyatu dengan ruang tempat bermain anak dan ruang laktasi di gedung Pengadilan Agama Purwakarta.

Selain itu dalam optimalisasi pelayanan kepada masyarakat, di Pengadilan Agama Purwakarta juga disediakan fasilitas untuk penyandang difable ${ }^{17}$ seperti : a. Kursi roda, b. Toilet khusus, c. Jalur kursi roda. Dengan demikian, sangat terlihat Pengadilan Agama Purwakarta terus berusaha dalam optimalisasi pelayanan kepada masyarakat khususnya kepada para pencari keadilan, termasuk penyandang difable juga diprioritaskan.

\footnotetext{
${ }^{15} \mathrm{Ibid}$.

${ }^{16}$ Abdul Ghaffar Mubtadi, Sekretaris Pengadilan Agama Purwakarta, Wawancara Mendalam, 2 ${ }^{17}$ Ibid. November 2020
}

136 | Muttaqien: e-ISSN : 2723-5963 
Berkaitan dengan optimalisasi pelayanan kepada masyarakat juga, Pengadilan Agama Purwakarta terus melakukan terobosan dan inovasi ${ }^{18}$, salah satunya dalam hal garansi pelayanan. Para pencari keadilan di Pengadilan Agama Purwakarta, apabila mengalami keterlambatan dalam hal pelayanan, dia akan mendapat satu (1) souvenir. Dengan demikian, semakin banyak keluar souvenir berarti terlihat pelayanan di Pengadilan Agama Purwakarta kurang optimal.

Terakhir, berdasarkan informasi dari Sekretaris Pengadilan Agama Purwakarta, dalam upaya optimalisasi pelayanan kepada masyarakat masih ada beberapa hal yang belum terlaksana ${ }^{19}$ yaitu :

a) Rambu-rambu penunjuk arah Pengadilan Agama Purwakarta.

b) Penerangan jalan umum di depan gedung Pengadilan Agama Purwakarta.

c) Ruang sidang keliling yang difasilitasi oleh Pemerintah Daerah.

d) Perubahan status penduduk dimana produk hukum yang dihasilkan selaras dengan Disdukcapil supaya hasil lebih cepat dan akurat.

Hal ini juga merupakan harapan dari Pengadilan Agama Purwakarta dengan bekerjasama dengan instansi lain, sehingga pelayanan prima kepada masyarakat khususnya para pencari keadilan dapat terus diwujudkan.

\section{Penutup}

Berdasarkan hasil penelitian maka dapat disimpulkan sebagai berikut :

1. Unsur-unsur perubahan yang terjadi dalam perkembangan Pengadilan Agama Purwakarta, antara lain :

a. Sarana prasarana. Sejak zaman penjajahan Hindia Belanda, di Purwakarta telah berdiri Pengadilan Agama yang pada waktu itu disebut Raad Agama. Awal berdirinya gedung kantor Pengadilan Agama Purwakarta beralamat di Jalan Gandanegara No. 25 Purwakarta berdampingan dengan Setda Purwakarta serta Rumah Dinas Bupati Purwakarta, dengan kondisi gedung yang sederhana. Mengingat gedung yang lama

\footnotetext{
${ }^{18}$ Adam Iskandar, Panitera Pengadilan Agama Purwakarta, Wawancara Mendalam, 3 Nove mber 2020. Senada dengan hal itu, juga diungkapkan oleh N. Kesih, Panmud Hukum Penga dilan Agama Purwakarta, Wawancara Mendalam, 3 November 2020

${ }^{19}$ Abdul Ghaffar Mubtadi, Sekretaris Pengadilan Agama Purwakarta, Wawancara Mendalam, 2 November 2020
} 
sudah tidak representatif, barulah pada tahun 2016 Pengadilan Agama Purwakarta menempati gedung baru setelah selesai dibangun dengan anggaran dari Mahkamah Agung RI. Gedung baru Pengadilan Agama Purwakarta itu terletak di Jalan Ir. H. Djuanda Nomor 03 Purwakarta. Fasilitas pendukung juga dibangun sebagai upaya pelayanan prima kepada para pencari keadilan.

b. Reformasi birokrasi. Pelaksanaan Reformasi Birokrasi dan Pembangunan Zona Integritas menuju Wilayah Bebas Korupsi (WBK)/Wilayah Birokrasi Bersih dan Melayani (WBBM) dilaksanakan Mahkamah Agung dan badan peradilan yang ada di bawahnya bertujuan untuk meningkatkan kualitas kinerja organisasi dan membentuk SDM (Sumber Daya Manusia) aparatur peradilan yang profesional. Termasuk Pengadilan Agama Purwakarta juga melaksanakan Zona Integritas ini.

c. Jumlah perkara yang diputus. Mengenai jumlah perkara yang diterima dan diselesaikan oleh Pengadilan Agama Purwakarta dari tahun ke tahun terutama rentang waktu tahun 2016-2020 terlihat ada peningkatan. Apalagi dengan adanya Pembangunan Zona Integritas menuju WBK/WBBM, terlihat kesadaran hukum masyarakat juga meningkat. Kondisi sosial masyarakat juga mempengaruhi jumlah perkara yang diselesaikan oleh Pengadilan Agama Purwakarta.

2. Dasar pertimbangan perubahan Pengadilan Agama Purwakarta dilakukan, antara lain:

a. Kondisi sosial budaya masyarakat. Pengadilan Agama Purwakarta berkembang dengan memperhatikan perkembangan hukum dan masyarakat di Kabupaten Purwakarta, kondisi internal Pengadilan Agama Purwakarta serta dengan memperhatikan kondisi perkembangan hukum dan masyarakat secara nasional. Pengadilan Agama Purwakarta terus melakukan perubahan. Perkembangan dunia digital tidak lagi sekedar mempengaruhi bahkan merubah perilaku dan kebiasaan masyarakat. Digitalisasi kehidupan yang semakin berkembang pesat ke depan ini juga dimanfaatkan oleh Pengadilan Agama Purwakarta.

b. Optimalisasi pelayanan di Pengadilan Agama Purwakarta. Melalui Pelayanan Terpadu Satu Pintu (PTSP) Mahkamah Agung ingin memberikan pelayanan prima dalam hal pelayanan publik yang proses pengelolaannya dimulai dari tahap awal sampai akhir/terbitnya sebuah dokumen dilakukan di dalam satu tempat. 
Pengadilan Agama Purwakarta sebagai lembaga Peradilan di bawah Mahkamah Agung, bahwa sejak tahun 2018 Pengadilan Agama Purwakarta sudah mulai menerapkan standar PTSP sesuai Keputusan Direktur Jenderal Badan Peradilan Umum Nomor 77/DJU/SK/HM02.3/2/2018 tentang Pedoman Standar Pelayanan Terpadu Satu Pintu (PTSP) Pada Pengadilan Agama. Di samping itu, untuk optimalisasi pelayanan kepada masyarakat, Pengadilan Agama Purwakarta juga terus melengkapi sarana prasarana seperti mushalla dan fasilitas khusus untuk penyandang disabilitas. Kemudian Pengadilan Agama Purwakarta juga terus melakukan terobosan dan inovasi dalam rangka i pelayanan prima kepada para pencari keadilan.

\section{DAFTAR PUSTAKA}

[Silahkan ketik disini]

Daftar Pustaka hanya memuat sumber-sumber yang dirujuk dalam catatan kaki (footnote), dan semua sumber yang dirujuk harus tercantum dalam daftar rujukan. Sumber rujukan sebaiknya 80\% berupa pustaka terbitan 10 tahun terakhir. Rujukan yang digunakan adalah sumber-sumber primer berupa artikel-artikel penelitian dalam jurnal atau laporan penelitian (termasuk skripsi, tesis, disertasi). Setiap artikel, buku, dan sumber lainnya yang dikutip harus tercantum dalam pustaka acuan.

Ketentuan penulisan referensi secara alphabetic disesuaikan dengan format yang sudah ditentukan. Penulisan sebaiknya menggunakan aplikasi manajemen referensi seperti Mendeley. Format penulisan yang digunakan mengacu pada format APA $6^{\text {th }}$ Edition (American Psychological Association).

Sebagai panduan dalam melakukan sitasi dan menuliskan daftar referensi dapat mempelajari link berikut:

- http://flash1 r.apa.org/apastyle/basics/index.htm? ga=2.4551091.1894208228.1517201464$\underline{931692302.1508143966}$

- https://www.mendeley.com/guides/apa-citation-guide

- https://owl.english.purdue.edu/owl/resource/560/10/

- http://www.tandf.co.uk/iournals/authors/style/reference/tf apa.pdf

- $\underline{\text { https://www.itc.nl/library/papers/Mendeley.pdf }}$ 